\title{
EKSPERIMENTASI MODEL PEMBELAJARAN KOOPERATIF TIPE THINK PAIR SHARE (TPS) DENGAN PROBLEM POSING PADA POKOK BAHASAN PELUANG DITINJAU DARI ADVERSITY QUOTIENT (AQ) SISWA KELAS XI SMK DI KABUPATEN BOYOLALI TAHUN AJARAN 2013/2014
}

\author{
Hidayat Bahktiar ${ }^{1}$, Budi Usodo ${ }^{2}$, Riyadi $^{3}$ \\ ${ }^{1,2,3}$ Prodi Magister Pendidikan Matematika, PPs Universitas Sebelas Maret Surakarta
}

\begin{abstract}
This research aimed to find out: (1) which one gives better in mathematics learning achievement, learning model of Think Pair Share (TPS) with Problem Posing, Think Pair Share (TPS) or conventional, (2) which one have better in mathematics learning achievement, students having climbers, campers or quitters of Adversity Quotient, (3) in each learning model, which one have better mathematics learning achievement, students having climbers, campers or quitters of Adversity Quotient, (4) in each student's level of Adversity Quotient which one gives better in mathematics learning achievement, learning model of TPS with Problem Posing, TPS or conventional. This research was a quasi-experimental research with $3 \times 3$ factorial design. The population of the research was all students class XI majors group technology, health and agriculture of SMK in Boyolali. The samples were chosen by using stratified cluster random sampling. The instruments that were used to collect the data were the documentation of mathematics achievement, questionnaire of Adversity Quotient and test of mathematics achievement. The technique of analyzing the data was two-ways ANOVA with unbalanced cells. The result of research showed as follows: (1) learning model of TPS with Problem Posing provided better learning achievement than model of TPS and conventional, learning model of TPS provided better learning achievement than conventional, (2) the students having climbers and campers had same achievement, and the students having climbers and campers had better achievement than those having quitters, (3) in each learning model, the students having climbers and campers had the same achievement, and the students having climbers and campers had better achievement than those having quitters, (4) in each Adversity Quotient, learning model of TPS with Problem Posing provided better learning achievement than TPS and conventional, learning model of TPS provided better learning achievement than conventional.
\end{abstract}

Key words: Think Pair Share (TPS), Problem Posing, and Adversity Quotient (AQ)

\section{PENDAHULUAN}

Pendidikan merupakan usaha yang terencana untuk membantu meningkatkan perkembangan potensi bagi manusia agar bermanfaat bagi kepentingan hidupnya sebagai mahkluk pribadi maupun sebagai aggota masyarakat. Salah satu upaya untuk menempuh pendidikan adalah dengan cara menempuh suatu proses belajar. Dengan belajar, suatu proses perkembangan individu dan perkembangan masyarakat dapat dilihat.

Matematika sebagai salah satu ilmu dasar mempunyai peranan yang penting dalam berbagai bidang kehidupan, misalnya dapat dilihat dari banyaknya konsep-konsep matematika yang dapat digunakan baik dalam pengembangan ilmu pengetahuan dan teknologi maupun dalam kehidupan masyarakat sehari-hari. Hal ini juga sesuai dengan 
Ignacio, et. al (2006: 16) yang menyebutkan bahwa belajar matematika sudah menjadi kebutuhan bagi kemajuan seseorang dimasyarakat yang kompleks sekarang ini. Menurut Daryanto (2012: 240), matematika perlu diberikan kepada semua peserta didik mulai dari sekolah dasar untuk membekali mereka berpikir logis, analitis, sistematis, kritis, dan kreatif serta mampu bekerja sama. Artinya pembelajaran matematika di sekolah merupakan salah satu komponen pendidikan yang tidak hanya mengembangkan kemampuan dan keterampilan menerapkan matematika, melainkan mengembangkan kemampuan dalam memecahkan masalah yang berhubungan dengan matematika. Oleh karena itu, cara untuk mengembangkan kemampuan matematika siswa adalah dengan memposisikan siswa sebagai individu yang aktif dalam mengkonstruksikan pengetahuan melalui proses belajar yang interaktif.

Namun demikian, pembelajaran matematika jika dilihat dari prestasi belajar yang telah diperoleh menunjukkan hasil yang belum optimal. Hal tersebut juga terjadi di Kabupaten Boyolali yang diperoleh dari Pusat Penilaian Pendidkan Badan Penelitian dan Pengembangan Tahun 2012/2013. Dilihat dari daya serap pokok bahasan yang diujikan pada Ujian Nasional tahun 2012, pokok bahasan materi yang mempunyai daya serap rendah adalah materi Peluang. Pokok bahasan peluang di Kabupaten Boyolali mempunyai daya serap sebesar 39,99 \% sedangkan daya serap Nasional pada materi ini sebesar 41,61 \%. Hal ini dapat dikatakan bahwa siswa di SMK Kabupaten Boyolali masih mengalami kesulitan dalam menyelesaikan soal-soal yang berkaitan dengan materi Peluang.

Hal ini mungkin dikarenakan kurangnya pengertian siswa dalam memahami isi soal serta materi tentang peluang. Selain itu juga dipengaruhi kemampuan guru dalam menyampaikan materi pelajaran. Ketepatan guru dalam menggunakan pendekatan ataupun metode pembelajaran yang dilakukan oleh guru akan dapat membangkitkan semangat belajar siswa terhadap materi pelajaran yang diberikan sehingga berpengaruh terhadap hasil belajar siswa. Siswa akan mudah menerima materi yang diberikan oleh guru apabila pendekatan pembelajaran atau model pembelajaran yang digunakan tepat sehingga siswa dapat ikut aktif dalam proses kegiatan belajar mengajar.

Oleh sebab itu, untuk meningkatkan prestasi belajar siswa perlu suatu usaha dari guru dalam menciptakan proses pembelajaran yang kondusif agar kemampuan yang dimiliki siswa dapat berkembang dengan baik, sehingga dengan berkembangnya kemampuan siswa dapat meningkatkan prestasi belajar matematika siswa. Menurut Slameto (2003:76), pembelajaran matematika sangat ditentukan oleh strategi dan pendekatan yang digunakan dalam mengajar matematika itu sendiri. Belajar yang efisien 
dapat tercapai apabila dapat menggunakan strategi belajar yang tepat. Karena pentingnya matematika untuk dipelajari, maka perlu dihadirkan nuansa baru dalam praktik pembelajaran matematika salah satunya dengan melakukan pembelajaran dengan menggunakan model pembelajaran kooperatif. Jones \& Jones (2008: 63) menjelaskan bahawa pembelajaran kooperatif adalah salah satu yang paling baik diteliti dari semua strategi pengajaran, model pembelajaran kooperatif memungkinkan siswa untuk mengembangkan pemahaman mereka sendiri sebagai kunci pemahaman konsep, mendorong dan membantu orang lain.

Model pembelajaran kooperatif terdiri dari berbagai macam diantaranya Think Pair Share (TPS). Model pembelajaran tersebut dapat meningkatkan partisipasi siswa dalam pembelajaran, karena menyelesaikan tugasnya dalam kelompok dimana tiap kelompok hanya terdiri dari 2 orang. Lebih banyak memberikan kesempatan untuk kontribusi setiap anggota kelompok, karena memberi waktu yang lebih banyak kepada anggota kelompok untuk berpikir. Uraian tersebut didukung hasil penelitian diantaranya dari Edy Suprapto (2012) dimana pada penelitiannya menunjakkan bahwa prestasi belajar siswa yang diberikan pembelajaran dengan model TPS efektif dibandingkan dengan siswa yang diberikan model konvensinal. Ngozi (2009) menyimpulkan bahwa pembelajaran TPS lebih baik daripada konvensioanl dalam meningkatkan prestasi belajar.

Akan tetapi model pembelajaran Think Pair Share (TPS) juga memiliki kekurangan atau kelemahan. Menurut Anita (2008:46), kekurangan dari kelompok berpasangan (kelompok terdiri 2 orang siswa) adalah: lebih sedikit ide yang muncul dan tidak ada penengah jika terjadi perselisihan dalam kelompok. Berdasarkan kekurangan tersebut pada penelitian ini dilakukan modifikasi model pembelajaran Think Pair Share (TPS). Salah satu model pembelajaran inovatif yang dapat diterapkan dalam pembelajaran matematika untuk mengembangkan kemampuan pemahaman konsep matematika siswa adalah menggunakan problem posing. Dengan adanya tugas pengajuan soal (problem posing) akan menyebabkan terbentuknya pemahaman dan penguasaan yang lebih mantap pada diri siswa terhadap materi yang telah diberikan. Seperti yang di ungkapkan Lin (2004) menunjukkan bahwa Problem Posing bagi siswa dapat membangun pemahaman matematika siswa. Kegiatan itu akan membuat siswa lebih aktif dan kreatif dalam membentuk pengetahuannya dan pada akhirnya pemahaman siswa terhadap konsep matematika siswa lebih baik lagi.

Dalam pembelajaran sehari-hari, penyampaikan materi peluang masih menggunakan model pembelajaran konvensional yang metode pembelajarannya berupa 
ceramah dan tanya jawab, maka dalam penelitian ini mengambil satu kelas kontrol yang dalam pembelajarannya menggunakan model konvensional.

Selain model pembelajaran, setiap siswa mempunyai tingkat dan tipe kecerdasan (kemampuan) yang berbeda-beda, sehingga hal tersebut memiliki pengaruh terhadap bagaimana siswa dalam belajar. Salah satu tipe kemampuan yang mempengaruhi seseorang berhasil dalam melakukan suatu kegiatan adalah Adversity Quotient (AQ). Menurut Stoltz (2003:9), AQ merupakan kemampuan yang dibutuhkan untuk mencapai kesuksesan. AQ dapat memberi tahu seberapa jauh seseorang dapat bertahan menghadapi kesulitan dan kemampuan seseorang dapat mengatasinya.

Santos (2012) menyatakan bahwa pembelajaran dengan pengaplikasian AQ dapat digunakan dalam pengembangan program pembelajaran untuk membuat proses belajar mengajar menghasilkan peserta didik yang lebih fleksibel dan kompeten. Uraian-uraian di atas tersebut digunakan sebagai acuan untuk penelitian yang dilakukan dengan menggunakan AQ dan model pembelajaran untuk meningkatkan prestasi belajar matematika.

Penelitian ini mempunyai tujuan untuk mengetahui: (1) manakah yang menghasilkan prestasi belajar yang lebih baik antara siswa yang dikenai model pembelajaran TPS dengan Problem Posing, model pembelajaran TPS, atau model pembelajaran konvensional terhadap prestasi belajar siswa, (2) manakah yang mempunyai prestasi belajar lebih baik, antara siswa dengan AQ tipe climbers, campers, atau quitters, (3) pada masing-masing model pembelajaran, manakah yang menghasilkan prestasi belajar lebih baik pada siswa dengan AQ tipe climbers, campers, atau quitters, (4) pada masing-masing tipe AQ, manakah yang menghasilkan prestasi belajar lebih baik, siswa yang dikenai model pembelajaran TPS dengan Problem Posing, model pembelajaran TPS, atau model pembelajaran konvensional.

\section{METODE PENELITIAN}

Penelitian ini dilakukan di SMK di Kabupaten Boyolali Provinsi Jawa Tengah pada semester genap tahun pelajaran 2013/2014. Jenis penelitian adalah penelitian eksperimental semu (quasi experimental research). Populasi dalam penelitian ini adalah seluruh siswa SMK kelas XI di Kabupaten Boyolali tahun ajaran 2013/2014 dari 38 sekolah. Dalam penelitian ini, besaran sampel penelitian ditetapkan dengan stratified cluster random sampling, sehingga diperoleh SMK Negeri 1 Sawit dari sekolah berkemampuan tinggi, SMK Muhammadiyah 06 Simo dari sekolah berkemampuan sedang, dan SMK Muhammadiyah 01 Boyolali dari sekolah berkemampuan rendah. 
Teknik pengumpulan data menggunakan metode dokumentasi, metode tes, dan metode angket. Uji instrumen angket menggunakan uji validitas isi, konsistensi internal, dan reliabilitas. Uji instrumen tes prestasi yang digunakan adalah validitas isi, tingkat kesukaran, daya beda, dan reliabilitas. Uji instrumen angket dan uji instrumen tes prestasi belajar matematika dilakukan terhadap 68 siswa. Eksperimen dilakukan pada 310 siswa, dimana 103 siswa pada kelas eksperimen 1, 104 siswa pada kelas eksperimen 2, dan 103 siswa pada kelas kontrol. Data kemampuan awal maupun data prestasi belajar dilakukan uji prasyarat meliputi uji normalitas populasi menggunakan metode Lilliefors dan uji homogenitas variansi populasi menggunakan metode Bartlett. Sebelum melakukan eksperimen, dilakukan uji keseimbangan terhadap kemampuan awal matematika menggunakan anava satu jalan dengan sel tak sama. Uji hipotesis menggunakan analisis variansi dua jalan dengan sel tak sama. Apabila hasil analisis variansi menunjukkan bahwa hipotesis nol ditolak, dilakukan uji komparasi ganda menggunakan metode Scheffe'.

\section{HASIL PENELITIAN DAN PEMBAHASAN}

Hasil uji prasyarat menyimpulkan bahwa semua sampel berasal dari populasi yang berdistribusi normal dan populasi-populasi yang mempunyai variansi yang sama. Hasil uji keseimbangan diperoleh simpulan bahwa populasi mempunyai kemampuan awal yang seimbang.

Dengan taraf signifikansi 0,05 , berikut disajikan rangkuman hasil perhitungan analisis variansi dua jalan dengan sel tak sama.

Tabel 1. Rangkuman Analisis Variansi Dua Jalan dengan Sel Tak Sama

\begin{tabular}{lllllll}
\hline \multicolumn{1}{c}{ Sumber } & \multicolumn{1}{c}{ JK } & \multicolumn{1}{c}{$\mathbf{d k}$} & \multicolumn{1}{c}{$\mathbf{R K}$} & \multicolumn{1}{c}{$\boldsymbol{F}_{\boldsymbol{o b s}}$} & $\boldsymbol{F}_{\text {tabel }}$ & Keputusan Uji \\
\hline Model (A) & 2844,567 & 2 & 1422,283 & 10,201 & 3,026 & $H_{0 A}$ ditolak \\
AQ (B) & 1244,783 & 2 & 622,392 & 4,464 & 3,026 & $H_{0 B}$ ditolak \\
Interaksi (AB) & 7,001 & 4 & 1,750 & 0,012 & 2,402 & $H_{0 A B}$ diterima \\
Galat & 41963,334 & 301 & 139,413 & & & \\
\hline Total & 46059,685 & & & & & \\
\hline
\end{tabular}

Berdasarkan tabel di atas, hipotesis $H_{0 A}$ ditolak berarti terdapat pengaruh antar masing-masing model pembelajaran terhadap prestasi belajar matematika siswa. Jadi terdapat perbedaan prestasi belajar antara siswa yang dikenai model pembelajaran TPS dengan Problem Posing, siswa yang dikenai model pembelajaran TPS, dan siswa yang dikenai model pembelajaran konvensional. 
Karena $H_{0 A}$ ditolak maka perlu dilakukan uji komparasi rerata antar baris yang sebelumnya dicari dulu rerata marginalnya. Berikut disajikan rangkuman hasil perhitungan rerata marginal data.

Tabel 2. Rerata Data Antar Sel dan Rerata Marginal

\begin{tabular}{lcccc}
\hline \multirow{2}{*}{ Model } & \multicolumn{3}{c}{ AQ } & $\begin{array}{c}\text { Rerata } \\
\text { Marginal }\end{array}$ \\
\cline { 2 - 3 } & Quitters & Campers & Climbers & 66,641 \\
TPS & 62,889 & 67,000 & 68,480 & 71,038 \\
TPS \& PS & 67,333 & 71,652 & 72,471 & 62,408 \\
Kontrol & 58,400 & 63,238 & 63,800 & \\
Rerata Marginal & 62,714 & 67,438 & 68,065 & \\
\hline
\end{tabular}

Berikut ditunjukkan rangkuman uji komparasi rerata antar baris.

Tabel 3. Rangkuman Uji Komparasi Rerata Antar Baris

\begin{tabular}{lcccl}
\hline No. & $\boldsymbol{H}_{\mathbf{0}}$ & $\boldsymbol{F}_{\boldsymbol{o b s}}$ & $\mathbf{2 F}_{\mathbf{0 , 0 5} \mathbf{3 1 0}}$ & Keputusan Uji \\
\hline 1 & $\mu_{1 .}=\mu_{2 .}$ & 7,064 & 6,052 & $H_{0}$ ditolak \\
2 & $\mu_{2 .}=\mu_{3 .}$ & 27,919 & 6,052 & $H_{0}$ ditolak \\
3 & $\mu_{1 .}=\mu_{3 .}$ & 6,863 & 6,052 & $H_{0}$ ditolak \\
\hline
\end{tabular}

Hasil uji komparasi rerata antar baris menunjukkan bahwa siswa yang dikenai model pembelajaran TPS dengan Problem Posing memberikan pengaruh yang berbeda terhadap prestasi belajar matematika, jika dibandingkan dengan model pembelajaran TPS maupun model konvensional. Dilihat dari rerata marginalnya, diperoleh kesimpulan bahwa siswa yang dikenai model pembelajaran TPS dengan Problem Posing menghasilkan prestasi belajar yang lebih baik dibandingkan siswa yang dikenai model pembelajaran TPS dan model pembelajaran konvensional. Serta prestasi belajar matematika siswa yang dikenai model pembelajaran TPS lebih baik dibandingkan siswa yang dikenai model pembelajaran konvensional. Dengan demikian hipotesis pertama, yaitu model pembelajaran TPS dengan Problem Posing memberikan prestasi belajar lebih baik dibandingkan model pembelajaran TPS tanpa Problem Posing maupun konvensional terbukti kebenarannya pada taraf signifikansi $\alpha=5 \%$.

Hasil penelitian ini terkait dengan penelitian El Sayed (2000) yang menunjukkan bahwa dalam model pembelajaran yang menggunakan Problem Posing memberikan prestasi belajar yang lebih baik daripada model pembelajaran tradisional. Hal tersebut dimungkinkan karena model pembelajaran yang menggunakan Problem Posing dapat membangun pemahaman matematika siswa. Pemahaman matematika siswa tersebut dapat muncul ketika siswa membuat pertanyaan dan jawabannya yang mereka anggap sulit untuk temannya kerjakan. Dari kegiatan tersebut siswa akan merubah atau mengganti soal yang dirasa mereka mudah menjadi soal yang mereka anggap sulit, sehingga pemahaman matematika siswa dapat dibangun dari pembuatan soal tersebut. Seperti ditunjukkan Xia 
\& Wang (2008) dalam jurnal penelitiannya, problem posing dapat membangkitkan minat siswa dalam matematika, meningkatkan kemampuan siswa untuk menimbulkan masalah dan meningkatkan kemampuan belajar metematika mereka juga.

Berdasarkan Tabel $3 \mathrm{H}_{0 \mathrm{~B}}$ ditolak, maka perlu dilakukan uji komparasi ganda untuk tipe Adversity Quotient (AQ) siswa.

Tabel 4 Hasil Uji Komparasi Antar Kolom

\begin{tabular}{lcccc}
\hline No. & $\boldsymbol{H}_{\mathbf{0}}$ & $\boldsymbol{F}_{\boldsymbol{o b s}}$ & $\mathbf{2 F}_{\mathbf{0 , 0 5} ; \mathbf{3 1 0}}$ & Keputusan Uji \\
\hline 1 & $\mu_{.1}=\mu_{.2}$ & 6,083 & 6,052 & $H_{0}$ ditolak \\
2 & $\mu_{.2}=\mu_{.3}$ & 0,306 & 6,052 & $H_{0}$ diterima \\
3 & $\mu_{.1}=\mu_{.3}$ & 6,100 & 6,052 & $H_{0}$ ditolak \\
\hline
\end{tabular}

Dari Tabel 4 diperoleh kesimpulan bahwa siswa yang memiliki tipe AQ Climbers mempunyai prestasi belajar matematika yang sama dengan siswa yang memiliki tipe AQ Campers, serta siswa yang memiliki tipe AQ Climbers dan Campers mempunyai prestasi yang lebih baik daripada siswa yang memiliki tipe AQ Quitter.

Kesimpulan-kesimpulan di atas untuk hasil uji komparasi ganda pada siswa yang memilik tipe AQ Climbers dan Campers tidak sesuai dengan hipotesis dalam penelitian ini, yaitu siswa yang memiliki tipe AQ Climbers mempunyai prestasi belajar matematika yang lebih baik daripada siswa yang memiliki tipe AQ Campers, karena dari hasil uji komparasi ganda untuk tipe AQ Climbers dan Campers menunjukkan bahwa siswa yang memiliki tipe AQ Climbers dan Campers mempunyai prestasi belajar matematika yang sama. Adapun faktor yang menyebabkan tidak terujinya hipotesis ini yaitu dari pengamatan peneliti di lapangan siswa yang antara lain siswa yang memiliki tipe AQ Climbers belum bisa mengoptimalkan langkah-langkah dalam model pembelajaran dengan tipe AQ yang dimiliki siswa tersebut. Hal ini dikarenakan siswa terbiasa mendapatkan pembelajaran dengan cara mendengarkan guru dalam menyampaikan materi, melihat contoh-contoh soal yang diberikan oleh guru, serta menggunakan rumus yang diberikan tanpa mengetahui bagaimana cara untuk menyelesaikan suatu permasalahan berdasarkan ide dari pemahaman dan pengetahuan yang dimilikinya. Hal ini yang mungkin menyebabkan siswa yang memiliki AQ tipe Climbers mempunyai prestasi yang sama dengan siswa yang memiliki AQ tipe Campers. Akan tetapi hasil uji komparasi ganda pada siswa yang memiliki AQ tipe Campers dan Quitters sesuai dengan hipotesis pada penelitian ini yaitu siswa yang memiliki AQ tipe Campers mempunyai prestasi belajar matematika yang lebih baik daripada siswa yang memiliki tipe AQ Quitter. Untuk hasil uji komparasi ganda pada tipe AQ Climbers dan Quitters sesuai dengan hipotesis pada penelitian ini yaitu siswa yang memiliki tipe AQ 
Climbersmempunyai prestasi belajar matematika yang lebih baik daripada siswa yang memiliki tipe AQ Quitters.

Dari hasil uji komparasi ganda diperoleh siswa yang memiliki tipe AQ Climbers dan Campers mempunyai prestasi yang lebih baik daripada siswa yang memiliki tipe AQ Quitter. Hal tersebut sesuai dengan penelitian Alaine, et. al (2012) tentang hubungan antara AQ dan motivasi berprestasi menunjukkan bahwa terdapat hubungan yang signifikan antara AQ dan motivasi untuk berprestasi. Selain itu hasil penelitian ini juga sesuai dengan hasil penelitian yang dilakukan oleh Siti Nureini (2011), yang pada penelitiannya menunjukkan bahwa prestasi belajar matematika siswa pada tipe climbers lebih baik daripada prestasi belajar siswa pada tipe campers dan quitters. Begitu pula penelitian yang dilakukan oleh Eka Nur Azizah (2013) yang menunjukkan bahwa siswa dengan tipe Climbers mempunyai prestasi belajar yang sama dengan tipe Campers, dan siswa dengan tipe Climbers mempunyai prestasi belajar yang lebih baik daripada prestasi belajar pada siswa dengan tipe Quitters.

Karena $\mathrm{H}_{0 \mathrm{AB}}$ diterima, maka tidak perlu dilakukan uji komparasi ganda untuk model pembelajaran dan tipe Adversity Quotient (AQ) siswa, sehingga dapat disimpulkan bahwa pada masing-masing model pembelajaran, siswa yang memiliki tipe AQ Climbers dan Campers mempunyai prestasi belajar matematika yang sama, serta siswa yang memiliki tipe AQ Climbers dan Campers mempunyai prestasi yang lebih baik daripada siswa yang memiliki tipe AQ Quitter, sehingga pada model pembelajaran TPS dengan Problem Posing, siswa yang memiliki tipe AQ Climbers dan Campers mempunyai prestasi belajar matematika yang sama, serta siswa yang memiliki tipe AQ Climbers dan Campers mempunyai prestasi belajar matematika yang lebih baik daripada siswa yang memiliki tipe AQ Quitter. Hal ini tidak sesuai dengan hipotesis penelitian. Ada beberapa faktor yang menyebabkan tidak sesuainya hasil penelitian dengan hipotesis, diantaranya waktu pembelajaran yang terbatas, sehingga siswa dengan AQ Climbers atau siswa yang suka dengan tantangan belum maksimal dalam menggunakan kemampuannya AQ yang dimilikinya dalam pembuatan soal maupun dalam berdiskusi kelompok maupun diskusi kelas. Selain itu, siswa memiliki AQ tipe Climbers dan Campers saling aktif dalam proses pembelajaran berbeda dengan siswa yang memiliki AQ tipe Quitters yang pasif dalam proses pembelajaran.

Pada model pembelajaran TPS, siswa yang memiliki AQ tipe Climbers mempunyai prestasi belajar matematika yang sama dengan siswa yang memiliki AQ tipe Campers, serta siswa yang memiliki AQ tipe Climbers dan Campers mempunyai prestasi belajar matematika yang lebih baik daripada siswa yang memiliki AQ tipe Quitters. Hal 
ini sesuai dengan hipotesis penelitian. Ada beberapa faktor penyebabnya antara lain siswa memiliki AQ tipe Climbers dan Campers saling aktif dalam proses pembelajaran berbeda dengan siswa yang memiliki AQ tipe Quitters yang pasif dalam proses pembelajaran.

Pada model pembelajaran konvensional, siswa yang mempunyai AQ tipe Climbers mempunyai prestasi belajar matematika yang sama dengan siswa yang mempunyai AQ tipe Campers, serta siswa yang mempunyai AQ tipe Climbers dan Campers mempunyai prestasi belajar matematika yang lebih baik daripada siswa yang mempunyai AQ tipe Quitters. Hasil penelitian ini tidak sesuai dengan hipotesis penelitian. Ada beberapa faktor yang menyebabkan tidak sesuainya hasil penelitian dengan hipotesis. Faktor penyebab tersebut diantaranya antara lain siswa quitters terlihat sangat pasif di kelas karena pembelajarannya didominasi guru berbicara menerangkan materi, sehingga siswa hanya mendengarkan dan membuat catatan saja.

Kemudian, karena $\mathrm{H}_{0 \mathrm{AB}}$ diterima, maka tidak perlu dilakukan uji komparasi ganda untuk model pembelajaran dan tipe Adversity Quotient (AQ) siswa, sehingga dapat disimpulkan bahwa pada masing-masing tipe Adversity Quotient (AQ) siswa, model pembelajaran TPS dengan Problem Posing memberikan prestasi belajar matematika lebih baik daripada model pembelajaran TPS dan model pembelajaran konvensional, prestasi belajar matematika siswa yang dikenai model pembelajaran TPS lebih baik dibandingkan siswa yang dikenai model pembelajaran konvensional.

Hipotesis ketiga dan keempat yang tidak terpenuhi dimungkinkan karena ada faktor lain yang tidak dapat terkontrol berpengaruh terhadap proses penelitian antara lain, semangat belajar siswa yang masih kurang, siswa juga kurang disiplin dalam mengikuti pembelajaran matematika yang berakibat siswa tidak berkonsentrasi dan kurang memperhatikan materi pelajaran. Serta waktu yang ditargetkan terkadang tidak sesuai dengan kenyataan, karena kondisi waktu juga, siswa yang kurang mengerti materi yang dipelajari akan sulit bertanya karena tidak memungkinkan semua siswa bertanya mengenai materi.

\section{SIMPULAN DAN SARAN}

Berdasarkan hasil penelitian dan pembahasan, pada siswa kelas XI SMK di Kabupaten Boyolali pada materi Peluang disimpulkan berikut ini: (1) Prestasi belajar matematika siswa yang dikenai model pembelajaran TPS dengan Problem Posing lebih baik daripada prestasi belajar matematika siswa yang dikenai model pembelajaran Think TPS dan konvensional. Prestasi belajar matematika siswa yang dikenai model pembelajaran TPS lebih baik daripada prestasi belajar matematika siswa yang dikenai 
model pembelajaran konvensional. (2) Siswa yang memiliki Adversity Quotient (AQ) tipe climbers dan AQ tipe campers mempunyai prestasi belajar matematika yang lebih baik daripada siswa yang memiliki AQ tipe quitters, sedangkan siswa yang memiliki AQ tipe climbers mempunyai prestasi belajar matematika yang sama dengan siswa yang memiliki AQ tipe campers. (3) Pada model pembelajaran TPS dengan Problem Posing, model pembelajaran TPS dan model pembelajaran konvensional, siswa yang memiliki Adversity Quotient (AQ) tipe climbers mempunyai prestasi belajar matematika yang sama dengan siswa yang memiliki AQ tipe campers, sedangkan siswa yang memiliki AQ tipe climbers dan campers mempunyai prestasi belajar matematika yang lebih baik daripada siswa yang memiliki AQ tipe quitters. (4) Pada masing-masing tipe Adversity Quotient (AQ), prestasi belajar matematika siswa yang dikenai model pembelajaran TPS dengan Problem Posing lebih baik daripada prestasi belajar matematika siswa yang dikenai model pembalajaran TPS dan konvensional. Prestasi belajar matematika siswa yang dikenai model pembelajaranTPS lebih baik daripada prestasi siswa yang dikenai model pembelajaran konvensional.

Dari kesimpulan di atas, saran yang dapat diberikan kepada guru matematika yaitu untuk dapat menggunakan model pembelajaran yang inovatif dalam pembelajaran. Diantaranya model pembelajaran TPS dengan Problem Posing yang mampu membuat siswa mengkonstruksi pengetahuannya sendiri sehingga dapat digunakan untuk memecahkan masalah dalam kehidupan. Selain itu bagi peneliti lain dapat digunakan sebagai acuan atau dapat dipakai sebagai salah satu referensi untuk melakukan penelitian yang lain. Diharapkan para peneliti dapat mengembangkan model pembelajaran TPS dengan Problem Posing dengan menggunakan permainan dalam proses pembelajaran dengan memperhatikan variabel-variabel bebas lain seperti kemampuan berpikir kritis sehingga dapat menambah kualitas pendidikan yang lebih baik proses belajar mengajar menghasilkan peserta didik yang lebih fleksibel dan kompeten.

\section{DAFTAR PUSTAKA}

Alaine, G.L., Cornista dan Joy C.A.M. 2012. Adversity Quotient And Achievement Motivation Of Selected Third Year And Fourth Year Psychology Students Of DeLa Salle Lipa A. Y. 2012-2013. Tesis. DeLa Salle Lipa: The Faculty of the College of Education, Arts, and Sciences.

Anita Lie. 2008. Cooperative Learning. Jakarta : Grasindo.

Daryanto. 2012. Model Pembelajaran Inovatif. Yogyakarta: Gava Media.

Edy Suprapto. 2012. Eksperimentasi Model Pembelajaran Kooperatif Group Investigation (GI) dan Think-Pair-Share (TPS) Pada Materi Dimensi Tiga 
Dengan Pendekatan Pmri Ditinjau Dari Kreativitas Siswa. Thesis. Tidak diterbitkan. Surakarta : Universitas Sebelas Maret.

Eka Nur Azizah. 2013. Efektivitas Model Pembelajaran Kooperatif Tipe Numbered Heads Together (NHT) dengan Pendekatan Open-ended Pada Pembelajaran Matematika Ditinjau dari Adversity Quotient (AQ) Siswa SMA Negeri di Kota Mataram. Tesis. Tidak diterbitkan. Surakarta: Universitas Sebelas Maret.

El-Sayed, R.A. 2000. "Effectiveness of Problem Posing Strategies on Perspective Mathematics Teachers' Problem Solving Performance". Journal of Science and Mathematics Education in S.E. Asia. Vol.25, No.1, pp: 56-69

Ignacio, N.G., Blanco, L.J. dan Barona, E.G. 2006. "The Affective Domain In Mathematics Learning". International Electronic Journal of Mathemathics Education. Vol. 1, No. 1, pp. 16-32.

Jones, K.A. dan Jones, J. L. 2008. "Making Cooperative Learning Work in the College Classroom: An Application of the 'Five Pillars' of Cooperative Learning to Post-Secondary Instruction". The Journal of Effective Teaching. Vol. 8, No. 2, 2008, pp.61-76.

Ngozi, H.I. 2009. "Metacognitive Strategies on Classroom Participation and Student Achievement in Senior Secondary School Science Classrooms", Science Education International. Vol.20. No.1/2. 25-31.

Lin, P. 2004. "Supporting Teachers on Designing Problem-Posing Tasks As a Tool of Assessment to Understand Students' Mathematical Learning”. Psychology of Mathematics Education. Vol.3, pp:257-264.

Santos, M.C.J. 2012. "Assessing The Effectiveness Of The Adapted Adversity Quotient Program In Spesial Education School”. Journal Of Arts, Science \& Commerce. Vol. 3 Issue 4(2), pp: 13-23.

Siti Nureini. 2011. Eksperimentasi Pembelajaran Matematika dengan Model Pembelajaran Think Talk Write (TTW) dan Numbered Head Together (NHT) ditinjau dari Adversity Quotient Siswa Kelas VII SMP Di Surakarta. Tesis. Tidak diterbitkan. Surakarta: Universitas Sebelas Maret.

Slameto. 2003. Belajar dan faktor-faktor yang mempengaruhinya. Jakarta: Rineka Cipta.

Stoltz, P.G. 2003. Adversity Quotient: Mengubah Hambatan Menjadi Peluang. Jakarta: PT. Grasindo.

Xia, X., Lu, C. dan Wang, B. 2008. "Research on Mathematics Instruction Experiment Based Problem Posing". Journal of Mathematics Education. Vol. 1, No. 1, pp.153-163. 